\title{
Is Gurney's pitta Hydrornis gurneyi on the brink of extinction?
}

\author{
Nay Mro Shwe, Niti Sukumal, Mark Grindley and Tommaso Savini
}

\begin{abstract}
The remaining large patches of lowland forest in Tanintharyi, southern Myanmar, are the last global stronghold for the Endangered Gurney's pitta Hydrornis gurneyi. Except for a few individuals, the remaining population is now restricted to this forest, below $150 \mathrm{~m}$ altitude, mostly within the Nga Wun, Lenya, and Parchan Reserved Forests. However, as in much of South-east Asia, Tanintharyi has been subjected to extensive deforestation, particularly for oil palm cultivation. The aim of this research was to determine the extent of remaining habitat suitable for Gurney's pitta. During January-October 2016 we revisited 142 locations (of 147) where the species was detected during 2003-2012, and found it in only 41 of those locations (29\%); in all other locations the forest had been cleared. We measured the decline of suitable habitat since 1999 by examining all available intact forest in areas with elevations $<150 \mathrm{~m}$ and slope $<10^{\circ}$. In less than 2 decades suitable habitat has declined from 3,225 to $656 \mathrm{~km}^{2}(80 \%)$. Protection of remaining lowland forest is now critical. Although the expansion of oil palm cultivation has slowed since its peak in the early 200os, two national parks proposed by the Myanmar government in 2002, which would potentially offer legal protection for most of the remaining Gurney's pitta habitat, remain on hold because of political uncertainties. We recommend an alternative conservation approach for this species, based on an Indigenous Community Conserved Area model, and further research to improve knowledge of the species and to determine how it could be saved from extinction.
\end{abstract}

Keywords Deforestation, Gurney's pitta, habitat, Hydrornis gurneyi, Lenya National Park, Myanmar, South Tanintharyi, Sundaic lowland

\section{Introduction}

Clobal biodiversity has declined by $80 \%$ since 1970 J (Cardinale et al., 2012; Lanz et al., 2018). This trend is most accentuated in the tropical regions (Hoffmann

Nay Myo Shwe* (Corresponding author), Niti Sukumal and Tommaso SAVINI Conservation Ecology Program, King Mongkut's University of Technology Thonburi, Bangkok, Thailand. E-mail naymyo.shwe@fauna-flora.org

MARK Grindley Fauna \& Flora International, Myanmar Programme, Yangon, Myanmar

${ }^{*}$ Also at: Fauna \& Flora International, Myanmar Programme, Yangon, Myanmar

Received 6 March 2018. Revision requested 13 April 2018.

Accepted 12 September 2018. First published online 4 September 2019. et al., 2010), with South-east Asia expected to have the highest rate of vertebrate extinctions (Sodhi et al., 2004; Laurance, 2006; Gray et al., 2018). There are multiple causes of this, including overexploitation of wildlife to meet increasing demand for food, tonics and medicines, and trade in live animals (Nijman, 2010; Rao et al., 2011; Duckworth et al., 2012). However, the major cause of vertebrate declines in South-east Asia is the massive reduction in the extent and quality of natural habitats, particularly lowland tropical forests, as a result of legal and illegal logging and conversion of forest to large-scale agricultural production (Green et al., 2005; Sodhi et al., 2010; Clay, 2013).

The Tanintharyi Region, the most southerly part of Myanmar, on the Ismuth of Kra, falls within a zoogeographical transition zone between the Sundaic and Indo-Burmese subregions, supporting biological assemblages associated with both, including the Endangered Malay tapir Tapirus indicus, Critically Endangered Sunda pangolin Manis javanica, and Endangered Lar gibbon Hylobates lar (Woodruff \& Turner, 2009). This transition zone is a unique haven for biological diversity (Hughes et al., 2003; Donald et al., 2015), and is of major conservation importance for a range of lowland specialist bird species, including the regionally endemic and Endangered Gurney's pitta Hydrornis gurneyi and other species (Donald et al., 2009).

Tanintharyi has one of the largest areas of continuous lowland forest in mainland South-east Asia (Donald et al., 2015) and until recently was largely spared from the high rates of clearance occurring elsewhere in the region (Leimgruber et al., 2005). Since 1999, however, a large area of the Tanintharyi lowland forest has been converted to oil palm plantations as part of a government plan for national selfsufficiency in edible oils; this has seen at least $4,000 \mathrm{~km}^{2}$ in the Tanintharyi Region allocated to at least 44 oil palm companies (Baskett, 2015). Forest clearance has slowed since the election of a second democratic government in 2015 and in response to public and NGO pressure highlighting the negative environmental and social impacts of the oil palm industry and related illegal logging. Yet despite the cancellation of several concessions, oil palm cultivation remains a significant threat to Tanintharyi's biodiversity, as elsewhere in the region (e.g. Fitzherbert et al., 2008; Clay, 2013; Laurance et al., 2014a,b). Any significant further loss of this forest, already almost entirely lost from neighbouring Thailand and nearby Malaysia, would be catastrophic for lowland specialist species in particular.

One such specialist species is Gurney's pitta, which is naturally restricted to flat, lowland Sundaic moist evergreen forest between $7^{\circ}$ and $12.5^{\circ} \mathrm{N}$ latitude (Donald et al., 2014). 
The species was first described from Tanintharyi in 1875 (Hume \& Davison, 1878), but was not recorded for over 100 years until being rediscovered on the Thai side of the peninsula in June 1986 (Round \& Treesucon, 1986; Gretton et al., 1993). The species also occurs in Thailand but the population there has declined, mainly because its habitat is not protected. In 2013-2014 this population was reported to be functionally extinct (Round, 2014). A recent survey in Thailand in the remaining patches of potential habitat located only four individuals: two females detected visually and two males detected by calls (Thailand Wildlife Research Division, 2016). The species was first reconfirmed in southern Tanintharyi during field surveys in 2003 (Eames et al., 2005), followed by an estimate of a total range size of c. $3,300 \mathrm{~km}^{2}$ (Donald et al., 2014). A population estimate of 5,152-8,586 pairs (Eames et al., 2005) justified downlisting the species from Critically Endangered to Endangered in 2008 (BirdLife International, 2017). However, the increase in forest clearance for oil palm cultivation during Myanmar's political transition from military to civilian government led to a massive reduction in lowland habitat.

There is currently no strong evidence that the species is being targeted by collectors or hunters, although this possibility cannot be discounted as trade in the species occurred in the past (Round \& Treesucon, 1986). Nonetheless, understanding the extent, nature and impact of habitat loss on Gurney's pitta is essential for conservation planning for the species.

Although the current extent of occurrence of the species is defined as $26,700 \mathrm{~km}^{2}$ (BirdLife International, 2017), the estimate of the species' total range in Myanmar, using niche envelope modelling based on unconverted forest up to $300 \mathrm{~m}$ altitude, is $3,379 \mathrm{~km}^{2}$ (Donald et al., 2014), with no potentially suitable areas identified in Thailand. Although the species was rediscovered in 1986 in Thailand, it was only found in a single $30 \mathrm{~km}^{2}$ patch of lowland forest, in an area already disturbed and fragmented (Round \& Treesucon, 1986). It was subsequently discovered at four other sites in Thailand (Gretton et al., 1993). It was reported to inhabit forest with an understory of rattans, native trees and palms (Round, 1992), with a preference for areas with nearby streams or gullies (Gretton et al., 1993). However, recent surveys in Myanmar mostly recorded the species in degraded primary and bamboo forest inside Lenya and Nga Wun Reserved Forests (Saw et al., 2015).

Here our aim was to identify the remaining suitable habitat within the species' range and assess how much has been lost since commercial oil palm plantations began in southern Myanmar in 1999. We first compiled all known records of the species since its rediscovery in Myanmar in 2003, and used these to determine the species' elevation and slope preferences. We then used remote sensing data to identify the remaining forest coverage within the areas of suitable elevation and slope, and resurveyed for the species in these areas. Finally, we discuss the threats to the species and propose appropriate conservation actions.

\section{Study area}

The study was conducted in what is believed to be the remaining natural range of Gurney's pitta in the southern Tanintharyi Region (formerly Tenasserim Division), in southern Myanmar. The region is bounded by Mon State to the north, Thailand to the east and south, and the Andaman Sea to the west (Fig. 1a). The area has a dry season (November-March) with monthly rainfall of $<100 \mathrm{~mm}$, and a wet season (April-October) with a mean monthly rainfall of $750 \mathrm{~mm}$ (Baskett, 2015). We include all mainland forested areas in south Tanintharyi (mostly within Lenya, Nga Wun, Parchan and Tanintharyi Reserved Forests) from 10.7 to $12.5^{\circ} \mathrm{N}$ latitude, representing the limits of the species according to historical and recent observations (Eames et al., 2005; Donald et al., 2014).

\section{Methods}

Of the 149 locations where the species was detected during 2003-2016, 96.6\% (144 locations) were below $150 \mathrm{~m}$ altitude and $93 \%$ (139 locations) below $100 \mathrm{~m}$, with five records from above $150 \mathrm{~m}$, potentially of transient or non-breeding, dispersing animals (Round \& Treesucon, 1986; Lambert \& Woodcock, 1996; Round, 1996). We therefore defined suitable habitat as below $150 \mathrm{~m}$ and with slopes $<10^{\circ}$ (after Eames et al., 2005), and covered by closed-canopy forest and degraded primary forest with bamboo, following Donald et al. (2014) and Gretton et al. (1993). Elevation and slope maps were derived from the $30 \mathrm{~m}$ resolution ASTER Global Digital Elevation Map (NASA, 2011), and preferred elevation and slope ranges were determined using ArcGIS 10.3 (Esri, Redlands, USA).

To quantify habitat loss we analysed forest cover for 1999, 2003, 2012 and 2017, resulting in three time intervals. Landsat 5 satellite images were used to identify forest areas in 1999, 2003 and 2012, and Landsat 8 images for 2017 (USGS, 2017). The images were firstly classified into vegetated and non-vegetated areas, using the normalized difference vegetation index, with $\operatorname{ArcGIS}$. For each map, mangrove forest coverage (Tanintharyi Region Mangrove Forest dataset, 2016) was removed. Agricultural areas in 2003, 2012 and 2017 were excluded using a land-use layer obtained from unpublished Fauna \& Flora International data and from Baskett (2015). For 1999, the first year of the government's oil palm development programme (Baskett, 2015), no land-use data are available. However, before oil palm expansion there were only small agricultural patches covering not more than $10 \%$ of the total area, mainly used for subsistence by local 


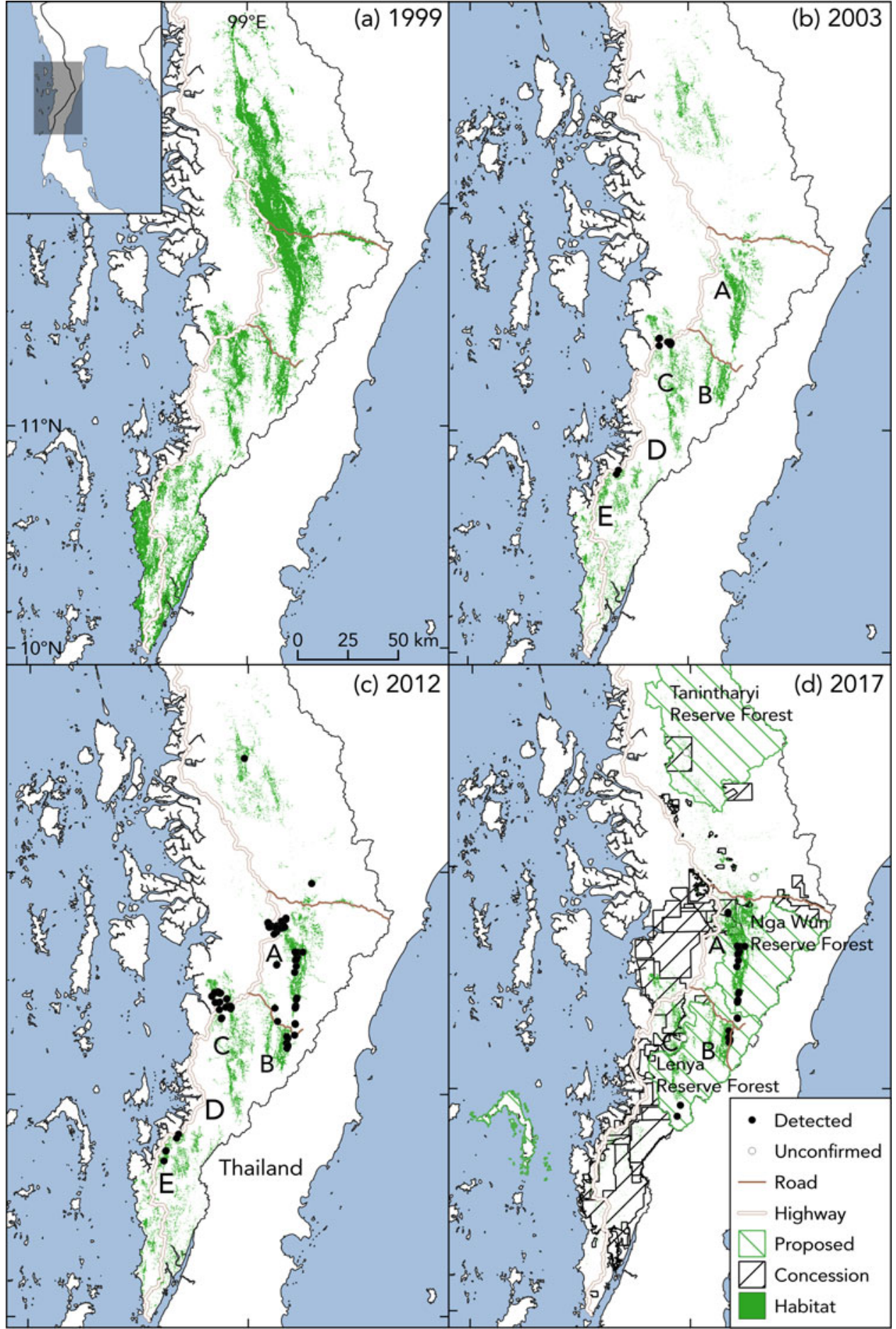

FIG. 1 Remaining habitat for Gurney's pitta Hydrornis gurneyi in south Tanintharyi, southern Myanmar, in (a) 1999, before oil palm plantations began, (b) in 2003 , when the species was rediscovered in 12 locations along the trans-Tanintharyi highway (the five main areas for the species (A-E) are from Fig. 6 of Eames et al., 2005), (c) in 2012 when the most extensive survey for the species was conducted (Donald et al., 2014), and (d) in 2017, with the majority of the suitable habitat in three main areas (A-C), and showing proposed protected areas, oil palm concessions and a new read along one of the valleys in area $\mathrm{B}$. villagers. Therefore, we assume that all identified vegetation areas in 1999 would have been forested. The potential range of Gurney's pitta in each year was then obtained by masking the resulting forest coverage for each of the four years with elevations $<150 \mathrm{~m}$ and slopes $<10^{\circ}$.

We collated the coordinates of all detections reported in Eames et al. (2005) and Donald et al. (2014), giving a total of 147 detections for 2003-2012. These comprised 12 records in
2003, 78 in 2007, 22 in 2008, nine in 2010, eight in 2011, and 18 in 2012. In addition, we included the locations of two records from camera-trap surveys we conducted in 2016 for tigers and their prey, giving a total of 149 locations. We attempted to revisit all of the 147 locations during JanuaryOctober 2016, with most points surveyed during MarchJune, the period of peak calling activity when response to playback calls is most likely (Gretton et al., 1993; Lin et al., 
2007; Round, 1996). At each site we sought to confirm if suitable habitat (i.e. closed-canopy evergreen, secondary forest with bamboo) was still present, and to determine the persistence or infer the absence of the species. The search for the species was facilitated by the use of playback calls, a method already shown to be effective for Gurney's pitta (Donald et al., 2014) and for other pitta species (Lin et al., 2007). At each site we played the call for 10 minutes; if no animal responded we waited 2-3 minutes and then played the call again for 10 minutes. This process was repeated a third time if no response was detected. Any areas recently converted for agriculture were noted. In $93 \%$ of the previously known 147 sites the species responded after the first playback, $2 \%$ after the second and $5 \%$ after the third.

\section{Results}

We estimate that prior to oil palm development (i.e. the 1999 baseline) the potential suitable habitat for Gurney's pitta was 3,055-3,395 $\mathrm{km}^{2}$ (Fig. 1a); the range incorporates $10 \%$ variability to account for small agricultural patches undetectable by our forest cover classification method. In 2003, when the species was rediscovered in Myanmar, suitable lowland evergreen forest within the species' range had already been reduced to $1,117 \mathrm{~km}^{2}$ (a $63-67 \%$ loss since 1999), with this remnant habitat concentrated in only five major areas (Fig. 1b), defined as areas of continuous, suitable habitat $>10 \mathrm{~km}^{2}$. By 2012, when the most extensive survey for the species was carried out (Donald et al., 2014), our analysis identified only $993 \mathrm{~km}^{2}$ of remaining suitable habitat across these five areas (Fig. 1C), a 3.5-4\% decrease since 2003. Our analysis for 2017 suggests only $656 \mathrm{~km}^{2}$ of suitable lowland forest remains, in just three major areas (Fig. 1d), a $42 \%$ loss since 2012. Overall, our analysis indicates that three of the five principal areas identified in 2003 and 2012 (Fig. 1b,c) still retained forest cover in 2017 , but were much reduced in area (Fig. 1d). Since large-scale development of palm oil plantations began in Tanintharyi in 1999 , c. $80 \%$ of Gurney's pitta habitat has been lost (i.e. 2,399-2,739 $\mathrm{km}^{2}$ ).

We were able to resurvey 142 of the 147 locations of previous records. Of these, 41 locations were still covered by vegetation suitable for the species (i.e. closed canopy forest or degraded primary forest with bamboo) and the species was detected. The remaining 101 sites were fully degraded, logged or otherwise cleared. Five locations could not be reached for logistical and security reasons.

Currently none of the $656 \mathrm{~km}^{2}$ of remaining habitat is under any formal conservation management. However, c. $40 \%$ of areas B and C (Fig. 1d) lies within Lenya Reserved Forest, which was selectively logged by the then Myanmar Forest Department through to the end of the 1990s, but proposed in 2002 as Lenya National Park. Another $40 \%$ of area A falls within the proposed Lenya
National Park extension (currently Nga Wun Reserved Forest; Fig. 1d), which was proposed in 2004. The remaining $131 \mathrm{~km}^{2}(20 \%)$ of Gurney's Pitta habitat occurs in small isolated patches within existing oil palm concessions (Fig. 1d). Overall, $80 \%$ of the remaining habitat falls in areas under the complete or partial control of the Karen National Union, an ethnic government that signed a ceasefire agreement with the Myanmar government in 2015 and that is engaging in negotiations over a peace settlement and federalism. The Karen National Union and Karen civil society have a strong desire to establish community-based conservation in these areas (NMS \& MG, pers. obs. 2015-2018; CAT, 2018; TRIPNET, 2018). Fauna \& Flora International and other organizations are currently helping Karen groups pursue these objectives.

\section{Discussion}

Our assessment indicates that $>80 \%$ of Gurney's pitta habitat has been lost since 1999, mostly to large-scale oil palm plantation. The species' population is likely to have declined similarly, and this is borne out by a lower encounter rate for the species in 2016 and 2017 compared to 2012 (NMS, NS \& TS, pers. obs.). Most previously known sites of Gurney's pitta have been obliterated by clearance for both large-scale oil palm and small-scale rubber and betel nut Areca catechu plantations (Bhagwat et al., 2017). Our findings are of concern for the rich biodiversity restricted to lowland forest in the transition zone between the Sundaic forest and the Isthmus of Kra (Hughes et al., 2003). Following the almost complete loss of this forest in neighbouring Thailand, to agriculture and for the development of infrastructure such as dams (Irvin et al., 2018), the only remaining patches are in Myanmar.

Our estimate of only $656 \mathrm{~km}^{2}$ of remaining habitat is far less than the previous estimate of $3,379 \mathrm{~km}^{2}$ (Donald et al., 2014). Donald et al. (2014) used MaxEnt, however, which tends to overestimate land coverage because it uses only presence records (Elith et al., 2011), and included forests up to $300 \mathrm{~m}$ altitude and relatively disturbed habitats in which the species can be found but may have limited survival. In our analysis, however, we estimated the area of remaining suitable habitat using a conservative approach, focusing only on conditions suitable for the long-term survival of the species. The large difference between our estimate of remaining habitat and BirdLife's (2017) estimate of $26,700 \mathrm{~km}^{2}$ is because the latter is based on the species' extent of occurrence (the minimum convex polygon that contains all sites of occurrence).

For 2003, when Gurney's pitta was rediscovered in Myanmar, we identified five major areas for the species (located along the trans-Tanintharyi highway; Fig. 1b). During their 2003 survey Eames et al. (2005) recorded the species in two major areas (areas C and D in Fig. 1b). One 
of these areas (D) has since been deforested. The three remaining areas for the species (A, B and C; Fig. 1c) were further reduced by 2012, when the most extensive survey for the species was concluded (Donald et al., 2014).

The greatest threat to Gurney's pitta is the expansion of oil palm cultivation from the late 1990 os onwards, responsible for most of the forest loss between then and 2015. In 2015, based on a detailed assessment of the social and environmental sustainability of oil palm in the region, there was a call for a moratorium on any new forest clearing (Baskett, 2015; FFI, 2016). The new government of the National League for Democracy, which took office in May 2016, subsequently launched a review that was ongoing as of February 2019 but that has led to the cancellation of some concessions.

By 2017 the remaining $656 \mathrm{~km}^{2}$ of habitat was in three areas, separated by higher elevations that may make them functionally isolated. New access roads are being built for military purposes along the Myanmar-Thailand border and along one of the valleys in area B (Fig. 1d). The surfacing and subsequent widening of the trans-Tanintharyi highway cleared two Gurney's pitta areas (Fig. 1b; Hla et al., 2003). Moreover, the road connecting Myanmar to the Thai border crossing of Dan Singkhon, currently being widened, delimits the northern edge of area A (Fig. 1d). The recently opened Boke Pyin to Yadanaporn-Khaloneloi road bisects the largest patch of remaining forest between areas A and B (Fig. 1d). Curtailment of agricultural encroachment along both civilian and military roads is a priority for maintenance of what is left of the habitat of Gurney's pitta.

The lack of protection of lowland forest was the main reason for the functional extinction of the species in neighbouring Thailand (Round, 2014). None of the remaining Gurney's Pitta habitat in Myanmar is under any form of legal protection or conservation management. Although the reserved forests offer some protection from expansion of commercial agriculture, the limited resources for law enforcement make it difficult for the township forest department officers to police large and remote areas and keep small-scale agricultural expansion and logging in check. A further constraint is that formal gazettement of the proposed Lenya National Park and its extension are currently delayed because of long-running disputes over land ownership and user rights between the Myanmar government, local and Indigenous communities, ethnic leadership and Indigenous organizations. A further confounding factor is the possible return of peoples displaced by $>60$ years of conflict between the Myanmar army and ethnic groups, a right that is recognized in law but for which there are currently no plans.

Much of the remaining Gurney's pitta habitat lies within areas controlled by the Karen ethnic group and they are key stakeholders in any future conservation management for the species. The Indigenous and Community Conservation Area model has been proposed as a solution for protection of both biodiversity and customary village forests by ethnic
Karen residents of Tanintharyi (CAT, 2018), and this offers the possibility of engaging with Indigenous communities on conservation management. The nationally and internationally well-known Gurney's pitta could potentially be adopted as a symbol of unity and peace between ethnic communities and the Tanintharyi and Myanmar governments.

Hunting is an additional, although indirect, threat to Gurney's pitta. During the 2016 surveys we noted a significant rise in the use of drift nets for hunting ground-dwelling species. Although primarily targeting the pangolin, the nets also pose a threat to Gurney's pitta as it spends much of its time on the ground.

The population size of Gurney's pitta is currently unknown but the decline of suitable habitat for the species and lack of legal protection, and continuing forest degradation, increase the possibility that the species could go extinct in the near future. Distance sampling surveys are required in the remaining habitat areas we have identified, to establish a baseline for monitoring the population and for the establishment of a conservation management strategy.

The rapid decline in habitat for Gurney's pitta and the implied decline of the population indicate that the species should be recategorized as Critically Endangered based on the Red List criteria (IUCN, 2012) A2c; i.e. a reduction in population size (A) based on an inferred population size reduction of $\geq 80 \%$ (2), and a decline in extent of occurrence (c). Recategorization of the species would not only reflect its precarious future but also focus attention on the decimation of its globally unique, lowland forest habitat.

Acknowledgements We thank the Forest Department of the Ministry of Natural Resources and Environmental Conservation for granting permission to conduct the 2016 surveys; Yuzanna II oil palm company for help with logistics; Philip D. Round for support and for sharing his knowledge of Gurney's pitta; George A. Gale, Matt Grainger, Dusit Ngoprasert and two anonymous reviewers for comments; Myo Myint Aung and Carl Reeder (Fauna \& Flora International) for assistance with maps and landscape analysis; Paul Donald for providing the location data of detections of Gurney's pitta from the 2003-2013 surveys; all Fauna \& Flora International's field biologists in Tanintharyi, particularly Saw Soe Aung and Aung Si Hein, and Maung Zaw, Wai Yan, Myint Naing Oo, Chit Min Oo, Kyaw San, and other village conservation group members from Yadanaporn village in Boke Pyin Township. The 2016 field work and subsequent analysis were undertaken by NMS as part of an ongoing PhD, sponsored by a KMUTT Petchra Pra Jom Klao Scholarship (Diamond scholar 18/2558). This research was supported by the EU, Helmsley Charitable Trust and Segre Conservation Foundation, through the FFI Tanintharyi Conservation Programme. The contents of this article are the sole responsibility of the authors and can under no circumstances be regarded as reflecting the position of the EU or other funders.

Author contributions Project design: NMS, NS, TS; data collection NMS; data analysis and writing: all authors.

\section{Conflicts of interest None.}


Ethical standards This research abided by the Oryx guidelines on ethical standards.

\section{References}

B Askett, J.P.C. (2015) Myanmar Oil Palm Plantations: a Productivity and Sustainability Review. Fauna \& Flora International, Yangon, Myanmar.

Bhagwat, T., Hess, A., Horning, N., Khaing, T., Thein, Z.M., AunG, K.N. et al. (2017) Losing a jewel-rapid declines in Myanmar's intact forests from 2002-2014. PLOS ONE, 12, eo176364.

Birdife International (2017) Hydrornis gurneyi. In The IUCN Red List of Threatened Species 2017: e.T22698628A118262214. Http:// dx.doi.org/10.2305/IUCN.UK.2017-3.RLTS.T22698628A118262214.en [accessed 8 December 2018].

Cardinale, B.J., Duffy, J.E., Gonzalez, A., Hooper, D.U., Perrings, C., Venail, P. et al. (2012) Biodiversity loss and its impact on humanity. Nature, 486, 59-67.

Cat (Conservation Alliance of Tanawthari) (2018) Our Forest, Our Life: Protected Areas in Tanintharyi Region Must Respect the Rights of Indigenous Peoples. Conservation Alliance of Tanawthari, Taninthayi, Myanmar.

Clay, J. (2013) World Agriculture and the Environment: a Commodity-by-Commodity Guide to Impacts and Practices. Island Press, Washington, DC, USA.

Donald, P.F., Aratrakorn, S., Htun, T.W., Eames, J.C., Hla, H., Thunhikorn, S. et al. (2009) Population, distribution, habitat use and breeding of Gurney's pitta Pitta gurneyi in Myanmar and Thailand. Bird Conservation International, 19, 353-366.

Donald, P.F., Hla, H., Win, L., Aung, T.D., Moses, S., Zaw, S.M. et al. (2014) The distribution and conservation of Gurney's pitta Pitta gurneyi in Myanmar. Bird Conservation International, 24, 354-363.

Donald, P.F., Round, P.D., Dai We Aung, T., Grindley, M., Steinmetz, R., Shwe, N.M. \& Buchanan, G.M. (2015) Social reform and a growing crisis for southern Myanmar's unique forests. Conservation Biology, 29, 1485-1488.

Duckworth, J.W., Batters, G., Belant, J.L., Bennett, E.L., Brunner, J., Burton, J. et al. (2012) Why South-east Asia should be the world's priority for averting imminent species extinctions, and a call to join a developing cross-institutional programme to tackle this urgent issue. Surveys and Perspectives Integrating Environment and Society, 5, 1327.

Eames, J.C., Hla, H., Laimgruber, P., Kelly, D.D., Aung, S.M., Moses, S. \& Tin, U.S.N. (2005) Priority contribution. The rediscovery of Gurney's pitta Pitta gurneyi in Myanmar and an estimate of its population size based on remaining forest cover. Bird Conservation International, 15, 3-26.

Elith, J., Phillips, S.J., Hastie, T., Dudík, M., Chee, Y.E., \& Yates, C.J. (2011) A statistical explanation of MaxEnt for ecologists. Diversity and Distributions, 17, 43-57.

FFI (Fauna \& Flora International) (2016) Fauna \& Flora International calls for oil palm moratorium to protect Myanmar's rainforest. Press release. Https://www.fauna-flora.org/news/faunaflora-international-calls-for-oil-palm-moratorium-to-protectmyanmars-rainforest [accessed 8 December 2018].

Fitzherbert, E.B., Struebig, M.J., Morel, A., Danielsen, F., BRÜh, C.A., Donald, P.F. \& Phalan, B. (2008) How will oil palm expansion affect biodiversity? Trends in Ecology \& Evolution, 23, $538-545$

Gray, T. N., Hughes, A. C., Laurance, W. F., Long, B., Lynam, A.J., O'Kelly, H. et al. (2018) The wildlife snaring crisis: an insidious and pervasive threat to biodiversity in Southeast Asia. Biodiversity and Conservation, 27, 1031-1037.

Green, R.E., Cornell, S.J., Scharlemann, J.P. \& Balmford, A. (2005) Farming and the fate of wild nature. Science, 307, 550-555.

Gretton, A., Kohler, M., Lansdown, R.V., Pankhurst, T.J., Parr, J. \& Robson, C. (1993) The status of Gurney's Pitta Pitta gumeyi, 1987-1989. Bird Conservation International, 3, 351-367.

Hla, H., Sein, M.A., Moses, S., Eames, J. \& Nyunt Tin, S. (2003) Gurney's Pitta Survey and Biodiversity Conservation Assessment in Tanintharyi Division. Unpublished report. Fauna \& Flora International, Yangon, Myanmar.

Hoffmann, M., Hilton-Taylor, C., Angulo, A., Böhm, M., Brooks, T.M., Butchart, S.H. et al. (2010) The impact of conservation on the status of the world's vertebrates. Science, 330, 1503-1509.

Hughes, J.B., Round, P.D. \& Woodruff, D.S. (2003) The Indochinese-Sundaic faunal transition at the Isthmus of Kra: an analysis of resident forest bird species distributions. Journal of Biogeography, 30, 569-580.

Hume, A.O. \& Davison, W. (1878) A revised list of the birds of Tenasserim. Stray Feathers, 6, 1-524.

IUCN (2012) IUCN Red List Categories and Criteria: Version 3.1, 2nd Edition. IUCN, Gland, Switzerland and Cambridge, UK.

Irvin, G.J., Round, P.D., SAvini, T., Lynam, A.J. \& Gale, G.A. (2018) Collapse of a tropical forest bird assemblage surrounding a hydroelectric reservoir. Global Ecology and Conservation, 16, eoo472.

Lanz, B., Dietz, S. \& Swanson, T. (2018) The expansion of modern agriculture and global biodiversity decline: an integrated assessment. Ecological Economics, 144, 260-277.

Lambert, F.R. \& Woodcock, M. (1996) Pittas, Broadbills and Asities. Pica, East Sussex, UK.

LAURANCE, W.F. (2006) Have we overstated the tropical biodiversity crisis? Trends in Ecology and Evolution, 22, 65-70.

Laurance, W.F., Sayer, J. \& Cassman, K.G. (2014a) Agricultural expansion and its impacts on tropical nature. Trends in Ecology \& Evolution, 29, 107-116.

Laurance, W.F., Clement, G.P., Sloan, S., O'Connell, C.S., Mueller, N.D., Goosem, M. et al. (2014b) A global strategy for road building. Nature, 513, 229-232.

Leimgruber, P., Kelly, D.S., Steininger, M.K., Brunner, J., Múller, T. \& Songer, M. (2005) Forest cover change patterns in Myanmar (Burma) 1990-2000. Environmental Conservation, 32, 356-364.

Lin, R.S., Lee, P.F., Ding, T.S. \& Lin, Y.T.K. (2007) Effectiveness of playbacks in censusing the fairy pitta (Pitta nympha) during the breeding season in Taiwan. Zoological Studies, 46, 242-248.

NASA (2011) Advanced Spaceborne Thermal Emission and Reflection Radiometer. Https://asterweb.jpl.nasa.gov/gdem.asp [accessed April 2017].

Nijman, V. (2010) An overview of international wildlife trade from Southeast Asia. Biodiversity and Conservation, 19, 1101-1114.

RAO, M., ZAw, T., HTUn, S. \& Myint, T. (2011) Hunting for a living: wildlife trade, rural livelihoods and declining wildlife in the Hkakaborazi National Park, north Myanmar. Environmental Management, 48, 158-167.

Round, P.D. (1992) Gurney's Pitta: the latest chapter. Oriental Bird Club Bulletin, 15, 29-32.

Round, P.D. (1996) On the seasonality and distribution of Gurney's pitta Pitta gurnforkeyi. Forktail, 11, 155-158.

Round, P.D. (2014) Gurney's pitta in Thailand, from rediscovery to extinction in just 28 years. Natural History Bulletin of the Siam Society, 6o, 3-8. 
Round, P.D. \& Treesucon, U. (1986) The rediscovery of Gurney's Pitta. Forktail, 2, 53-66.

SAw, M., Lay, W. \& Zockler, C. (2015) Avifauna of the Lenya Forests: Report on 2015 Bird Surveys in Southern Tanintharyi Region, Myanmar, and a Compilation of Other Recent Published and Unpublished Records. Report No. 21 of the Tanintharyi Conservation Programme, Fauna \& Flora International, the Myanmar Biodiversity and Nature Conservation Association, ArcCona Consulting and the Myanmar Forest Department. Fauna \& Flora International, Yangon, Myanmar.

Sodhi, N.S., Koн, L.P., Broок, B.W. \& NG, P.K. (2004) Southeast Asian biodiversity: an impending disaster. Trends in Ecology \& Evolution, 19, 654-660.

Sodhi, N.S., Posa, M.R.C., Lee, T.M., Bickford, D., Koh, L.P. \& BRook, B.W. (2010) The state and conservation of Southeast Asian biodiversity. Biodiversity and Conservation, 19, $317-328$.
USGS (U.S. Geological Survey) (2017) Earth Explorer. Https:// earthexplorer.usgs.gov [accessed September 2017].

Tanintharyi Region Mangrove Forest Dataset (2016) Source managed by Fauna \& Flora International. Http://geonode.themimu. info/layers/geonode\%3Affi_tni_mangrove_3om_2015 [accessed 8 December 2018].

TRipnet (Tanintharyi River Indigenous People Network) (2018) Growing up Together with the Forest: the Unique Relationship between the Forest and Indigenous Karen People of Kamoethway. Tanintharyi River Indigenous People Network, Kamoethway, Myanmar.

Wildlife Research Division Office (2016) The Report of Gurney's Pitta Population Surveys Year 2016. Wildlife Conservation Bureau, The Department of National Parks, Wildlife and Conservation, Bangkok, Thailand.

Woodruff, D.S. \& Turner, L.M. (2009) The Indochinese-Sundaic zoogeographic transition: a description and analysis of terrestrial mammal species distributions. Journal of Biogeography, 36, 803-821. 